\title{
Middle-Miocene transformation of tectonic regime in the Himalayan orogen
}

\author{
WANG XiaoXian ${ }^{1}$, ZHANG JinJiang $^{1 *}$, LIU Jiang $^{1}$, YAN ShuYu $^{1,2} \&$ WANG JiaMin ${ }^{1}$ \\ ${ }^{1}$ Key Laboratory of Orogenic Belts and Crustal Evolution, Ministry of Education, School of Earth and Space Sciences, Peking University, \\ Beijing 100871, China; \\ ${ }^{2}$ Petroleum Exploration and Development Research Institute, PetroChina, Beijing 100083, China
}

Received April 23, 2012; accepted July 11, 2012; published online August 27, 2012

\begin{abstract}
Understanding the multiple tectonic transformations during the Himalayan orogeny is significant in evaluating the evolution of Himalayan orogen. In the Gyirong area in south Tibet, deformed leucogranitic veins in the biotite-plagioclase gneisses of Greater Himalayan crystalline complex (GHC) constitute south-vergent asymmetric folds. The reconstruction of the veins shows that they experienced two generations of deformation under different tectonic regimes: an earlier top-to-north extension and a later top-to-south thrusting, implying a tectonic transformation from N-S extension to N-S shortening. Zircons LA-ICP-MS U-Pb dating of the leucogranite shows that it was emplaced during 21.03-18.7 Ma. The data suggest that the tectonic transformation occurred after 18.7 Ma. The chronological data of South Tibet detachment system (STDS) and North-South trending rift (NSTR) from Gyirong and other areas indicate that the Himalayan orogeny was in a period of tectonic transformation from N-S extension to N-S shortening during 19-13 Ma. The transformation of tectonic regime was probably controlled by the India-Asia convergence rate. An increase in the convergence rate resulted in N-S shortening of the orogen, thrusting and folding, with coeval formation of the NSTR in Tibet. A decrease in the convergence rate led to N-S extension and reactivation of the STDS.
\end{abstract}

leucogranitic vein, south Tibet detachment system (STDS), north-south trending rift (NSTR), tectonic regime transformation, Himalayan orogen, Gyirong area

Citation: Wang X X, Zhang J J, Liu J, et al. Middle-Miocene transformation of tectonic regime in the Himalayan orogen. Chin Sci Bull, 2013, 58: 108-117, doi: 10.1007/s11434-012-5414-6

The Himalayan orogen lies between the Yarlung Zangbo suture (YLZBS) to the north and the Main frontal Thrust (MFT) to the south, and comprises, from north to south, the Tethyan Himalaya sequence (THS), Greater Himalayan crystalline complex (GHC), Lesser Himalaya sequence (LHS) and Siwalik foreland basin sediments, separated by the south Tibet detachment system (STDS), Main Central Thrust (MCT), Main Boundary Thrust (MBT) and the MFT respectively (Figure 1) [1-3]. In southern Himalaya, the intense orogeny formed the south Himalayan thrust system, which consists of, successively from north to south, MCT, MBT and MFT. In contrast, the northern Himalayan domain is characterized by extensional structures including STDS, the north Himalayan gneiss dome (NHGD), and the north-

*Corresponding author (email: zhjj@pku.edu.cn) south trending rift (NSTR). Recent studies have revealed that the different orogenic processes were controlled by different tectonic regimes and the resultant structural architecture [1] as follows. (1) Prior to 36-32 Ma (from late Eocene to early Oligocene), the Himalayan orogen was controlled by $\mathrm{N}-\mathrm{S}$ contraction regime and experienced an early shorting and thrusting. (2) After early Oligocene, the tectonic regime transformed from N-S contraction to N-S extension. Between late Oligocene and early Miocene (28.416.2 Ma), the northern Himalayas experienced widespread extension, resulting in large scale extensional tectonics, such as the north-dipping STDS [4-16]. (3) In middleMiocene ( 13 Ma), the tectonic regime shifted to E-W extension $[17,18]$, which formed the NSTR cutting the STDS, such as Yadong-Gulu rift, Nima-Dingri rift and XainzaDinggye rift. Although the first transformation of tectonic 


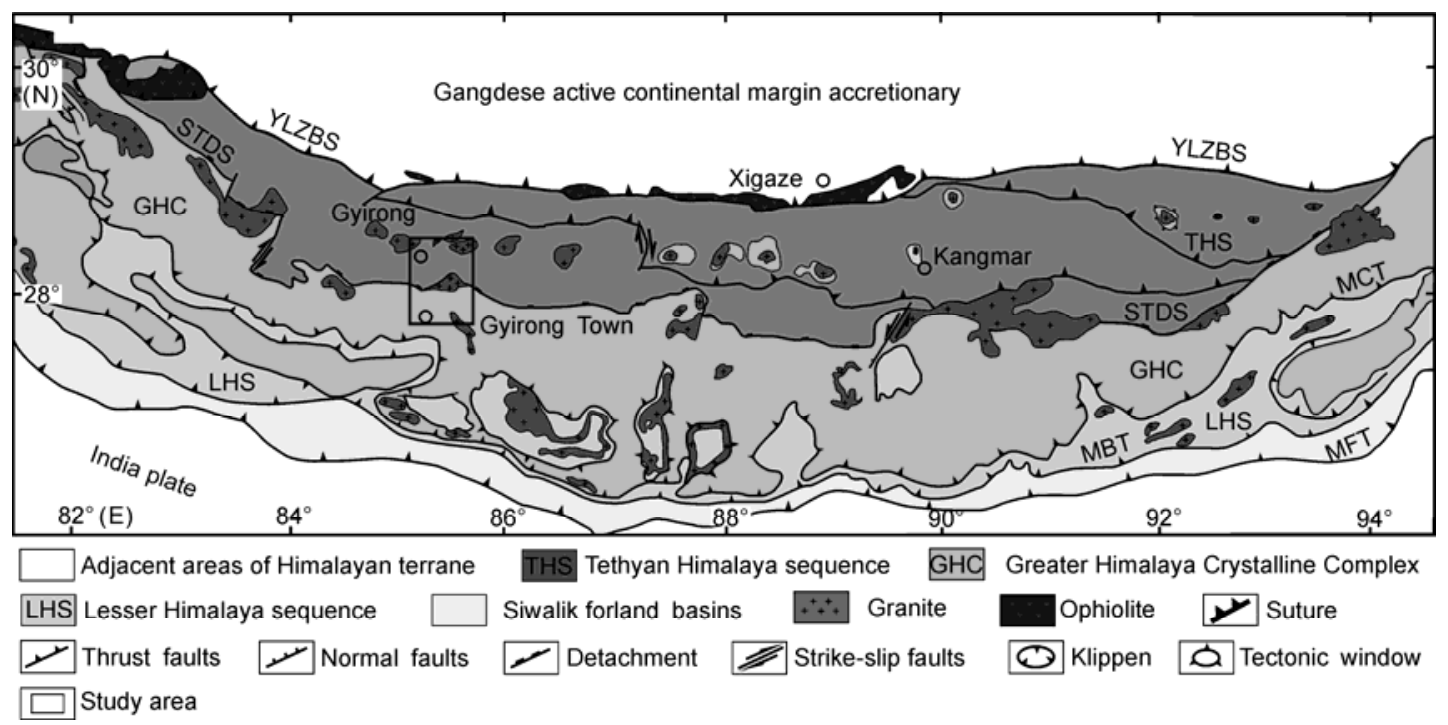

Figure 1 Sketch map of the Himalayan orogen (modified from [1,2]). YLZBS: Yarlung Zangbo suture; STDS: South Tibet detachement system; MCT: main central thrust; MBT: main boundary thrust; MFT: main frontier thrust.

regime from N-S contraction to N-S extension has been extensively studied [1,19-21], there have been no major investigations on the later transformation of tectonic regime from $\mathrm{N}-\mathrm{S}$ extension to $\mathrm{E}-\mathrm{W}$ extension.

In order to reveal this transformation of tectonic regime in the Himalayan orogen, we focus on the Gyirong area, where different kinds of structures related to the orogeny converge develop and intersect. This study provides a detailed structural analysis on the complexly deformed leucogranitic veins in the footwall of the STDS, and reports high-precision zircon LA-ICP-MS U-Pb ages on the veins, in an attempt to constrain the timing and geodynamic setting of the transformation of tectonic regime associated with the Himalayan orogeny.

\section{Geological setting and sample description}

The Himalayan orogen in Gyirong area can also be divided into five units from south to north: the GHC, the STDS, the THS, the late Cenozoic sedimentary basins and the NHGD (Figure 2) [1]. The GHC is composed of two components separated by a north-dipping fault. The southern part is composed of medium-grade metamorphic rocks, such as meta-sandstone and schist. The northern part consists of high-grade rocks, such as biotite-plagioclase gneiss, granitic gneiss and migmatite, into which leucogranitic veins intruded. The STDS in Gyirong area represents a large-scale ductile shear zone with a width of over $10 \mathrm{~km}$. It consists of mylonitic granitic gneiss and foliated leucogranite [22]. The THS forms the hanging wall of the STDS, mainly Paleozoic-Mesozoic sedimentary sequence, which was metamorphosed to slates and phyllites. The Cenozoic sedimentary basins in Gyirong area include Gyirong basin, Oma basin and some other small basins. Exposed to the north of Gyirong basin are Peiku Co and Malashan domes. These two domes are cored by two-mica granite/leucogranite and mylonitic granitic gneiss [23,24], mantled by garnet two-mica schist in the middle, and overlaid by the slate and phyllite of THS. The area of this study is located in the GHC where leucogranitic veins intruded into the gneiss (Figure 2) [1].

The leucogranite veins intruded into the biotite-plagioclase gneiss (Figure 3(a)), and occur as south-vergent asymmetric folds. The biotite-plagioclase gneiss, consisting of quartz, plagioclase, K-feldspar, biotite and muscovite, shows typical gneissic texture defined by the discontinuous alignment of biotites (Figure 3(b)). The leucogranite of sample TYC-88 is composed of quartz (45\%), plagioclase $(35 \%)$, K-feldspar (15\%), biotite and muscovite $(<5 \%)$, and minor chlorite. The quartz displays undulatory extinction and crenulated boundary (Figure 3(c)), probably caused by shearing. Some of the plagioclase grains show alternation to fine muscovite (Figure 3(d)).

\section{Analytical method}

We dated zircons from the leucogranitic vein from GHC in Gyirong area using LA-ICP-MS U-Pb method. The zircon grains were embedded in $25 \mathrm{~mm}$ epoxy discs and polished to approximately half of the grain thickness. The internal growth structure of zircons were analyzed by Cathodoluminescence (CL) imaging technique using a LEO 1450VP SEM, operating at $15 \mathrm{kV}$ and $150 \mu \mathrm{A}$ with a scanning time 1 $\mathrm{min}$, at the Institute of Geology and Geophysics, CAS. Zircon $\mathrm{U}-\mathrm{Pb}$ isotopic measurements were carried out on a Laser Ablation Inductively Coupled Plasma Mass Spectrometer at the 


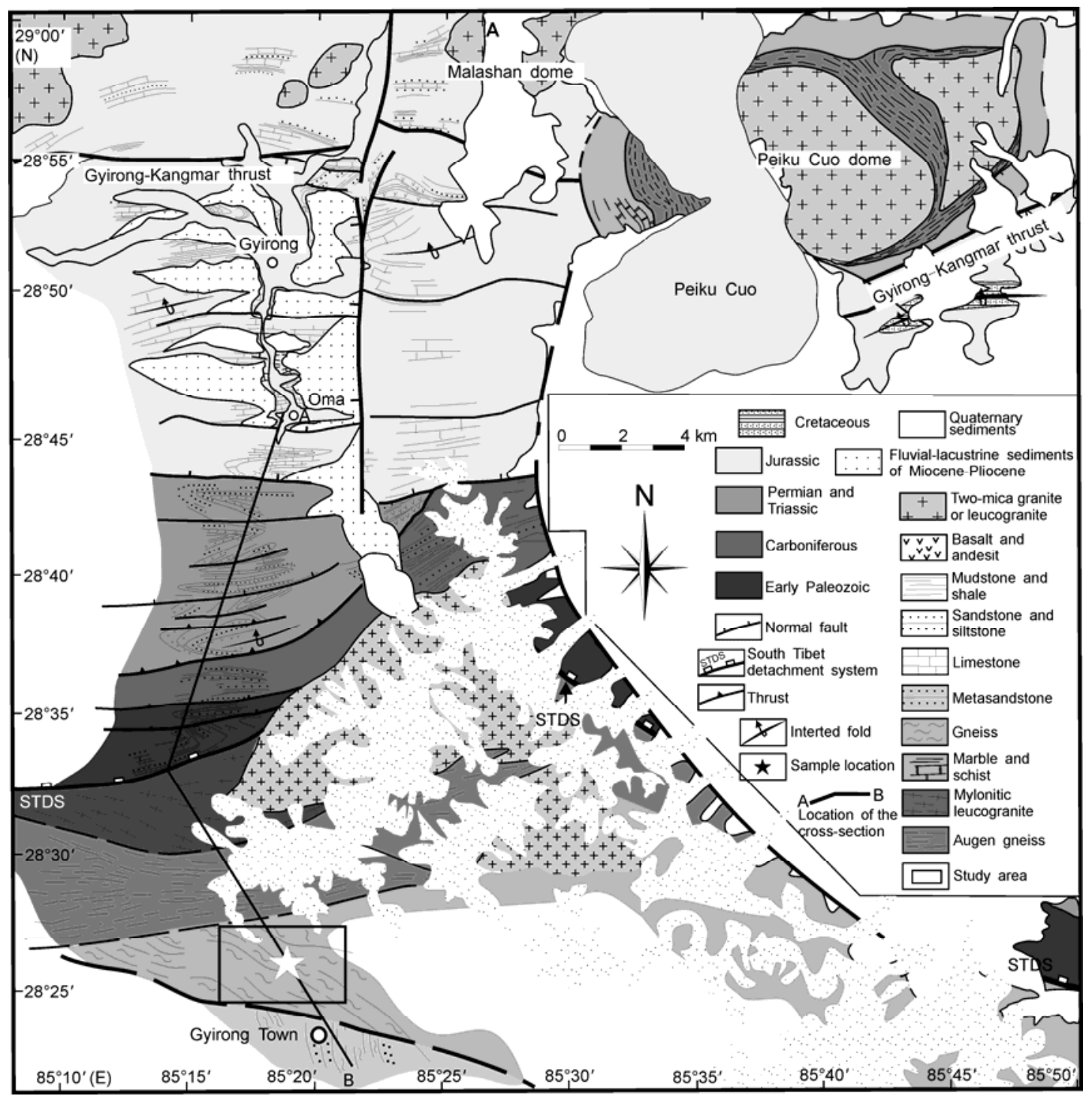

Figure 2 Geological map of the Gyirong area in northern Himalaya (after [1]).

LA-ICP-MS laboratory of the Key Laboratory of Continental Collision and Plateau Uplift, Institute of Tibetan Plateau Research, CAS, Beijing. Zircon grains were ablated with laser spots of $35 \mu \mathrm{m}$ and ablated depths of 20-40 $\mu \mathrm{m}$. PLE zircon (337 Ma) and NIST SRM 612 silicate were used as external standards for correcting mass fractionation and instrumental bias. Off-line isotope ratios and trace element concentrations were calculated by GLITTER_Ver4.0 [25]; $\mathrm{U}-\mathrm{Pb}$ concordia diagrams, weighted mean calculations and probability density plots of U-Pb ages were made by using Isoplot/Ex_ver 3 [26].

\section{Results}

The CL images of representative zircons (Figure 4) show that zircons in sample TYC-88 are euhedral with prismatic shapes and size ranging from 100 to $300 \mu \mathrm{m}$. The zircons show core-rim textures: the cores are dark with a spongy texture, probably caused by hydrothermal alteration, whereas the rims are bright with apparent oscillatory rings, indicating the magmatic origin [27].

Thirty-two spots were analyzed on the magmatic rim of the zircons from sample TYC-88, most of which plot well on the U-Pb Concordia (Figure 5 and Table 1). Nearly all the grains show low $\mathrm{Th} / \mathrm{U}$ values $(0.009-0.055)$. The thirtytwo spots yield apparent ${ }^{206} \mathrm{~Pb} /{ }^{238} \mathrm{U}$ ages from 26.8 to 18.2 $\mathrm{Ma}$. In the U-Pb concordia diagram, the age data are divided into two groups: the first group consists of eleven spots with ages ranging from 21.2 to $20.9 \mathrm{Ma}$, giving a weighted mean age of $21.03 \pm 0.11 \mathrm{Ma}(\mathrm{MSWD}=0.39$ ); the second group includes fifteen spots with ages from 19.2 to $18.2 \mathrm{Ma}$, giving a weighted mean age of 18.70 $\pm 0.19 \mathrm{Ma}(\mathrm{MSWD}=3.6)$. The features of similar oscillatory rings and low $\mathrm{Th} / \mathrm{U}$ ratios in rims of the two groups of zircons are consistent with magmatic zircons formed by anatexis [22]. We therefore 

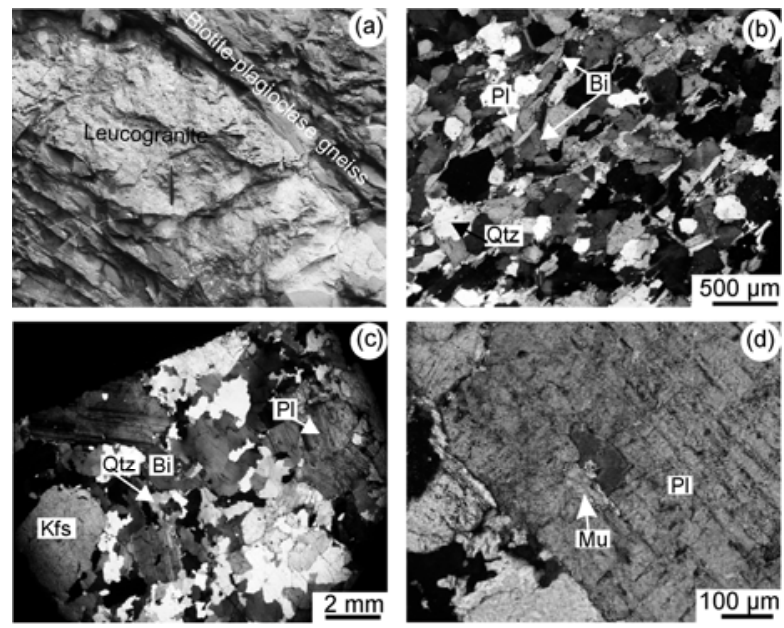

Figure 3 Photographs and photomicrographs of leucogranite and biotite-plagioclase gneiss from the GHC in Gyirong area. (a) Outcrops of leucogranite and the wall rock biotite plagioclase gneiss; (b) the gneissic texture defined by the discontinuous alignment of biotite; (c) mineral assemblage of leucogranite; (d) fine-grainedmuscovite altered from plagioclase. Qtz, Quartz; Kfs, K-feldspar; Pl, Plagioclase; Bi, Biotite; Mu, Muscovite.

consider these ages to represent the crystallization ages of the leucogranite. The range of the ages of leucogranite is in accordance with the age data from the Himalayan orogen, suggesting a long duration of anatexis [1].

\section{Discussion}

\subsection{Multiple episodes of deformation and tectonic transformation in Gyirong area}

The Himalayan orogen in Gyirong area experienced multiple episodes of deformation [1]. Based on the studies of structures and deformation of the Gyirong and the adjacent areas, Yang et al. [22] suggested three main stages of deformation: (1) an early south-directed thrusting preserved in the THS and GHC; (2) top-down-to-north slip along STDS; and (3) E-W extension, typically represented by the NSTR. Hence a transformation of tectonic regime occurred between each two episodes of deformation.

The leucogranitic veins in this study experienced a complex deformational history and they display south-vergent asymmetric folds, indicating south-directed thrusting (Figure $6(b))$. However, the reconstruction of the veins shows that they are composed of a series of asymmetric pudding or lenses which suggest a top-down-to-north shear (Figure 6(c)). These rocks thus experienced two generations of deformation in different tectonic regimes: an earlier top-downto-north extension and a later top-to-south thrusting and thickening, clearly marking a transformation in the tectonic regime in between. Combining with the zircon $\mathrm{U}-\mathrm{Pb}$ age of the leucogranite and geological history of the study area [1], we propose an evolutionary process as follows.

(1) Since $\sim 34$ to $\sim 19 \mathrm{Ma}$, the top-down-to-north slip along STDS controlled by the regime of N-S extension resulted in the partial melting of GHC [22]. The identical age of the leucogranitic veins and STDS demonstrates the emplacement and crystallization of leucogranite was synchronous with the STDS.

(2) After 18.7 Ma, the leucogranite veins underwent continued top-down-to-north extension, which formed the asymmetric puddings or lens and the neck structure between puddings (Figure 6(c)).

(3) Subsequently, the rocks experienced top-to-south thrusting and shortening under a N-S contractional tectonic regime, which formed the south-vergent asymmetric folds (Figure 6(d)).

The leucogranitic veins are adjacent to STDS but away from the MCT; furthermore, the deformation in MCT is reflected for several kilometers in the shear zone. Therefore the south-vergent geometry of the veins was not involved in the MCT, and should have resulted through the transformation of tectonic regime. As a result, we suggest that an

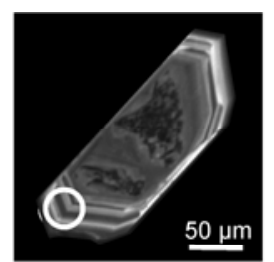

$21.0 \pm 0.24 \mathrm{Ma}$

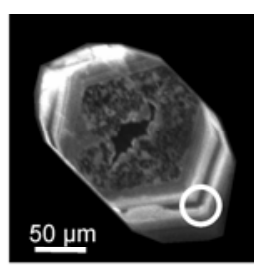

$21.1 \pm 0.18 \mathrm{Ma}$

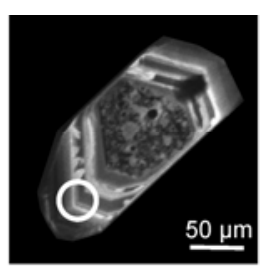

19.0 $\pm 0.17 \mathrm{Ma}$

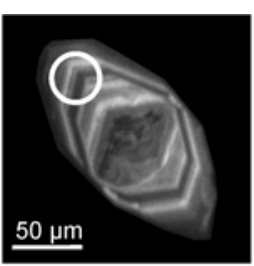

$19.8 \pm 0.17 \mathrm{Ma}$

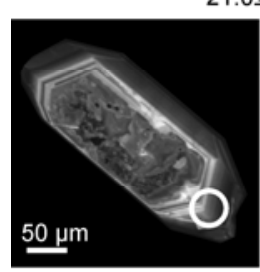

$18.4 \pm 0.36 \mathrm{Ma}$

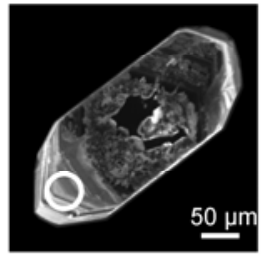

$21.1 \pm 0.20 \mathrm{Ma}$

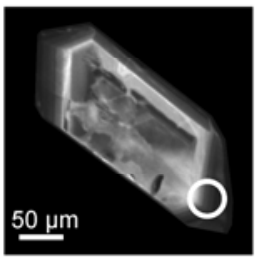

$21.2 \pm 0.21 \mathrm{Ma}$

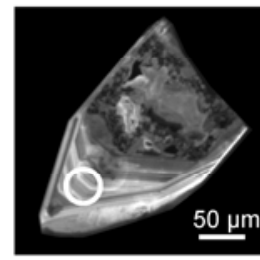

$18.9 \pm 0.19 \mathrm{Ma}$

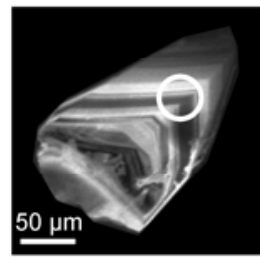

$18.2 \pm 0.16 \mathrm{Ma}$

Figure 4 CL images of representative zircons in sample TYC-88 from the leucogranite in GHC. 
Table 1 Zircon LA-ICP-MS U-Pb analytical data of the leucogranitic vein from Gyirong

\begin{tabular}{|c|c|c|c|c|c|c|c|c|c|c|c|c|c|c|c|c|c|}
\hline \multirow{2}{*}{$\begin{array}{c}\text { Analytical } \\
\text { spot }\end{array}$} & \multirow{2}{*}{$\begin{array}{c}\text { Th } \\
(\mathrm{ppm})\end{array}$} & \multirow{2}{*}{$\underset{(\mathrm{ppm})}{\mathrm{U}}$} & \multirow{2}{*}{$\mathrm{a} / \mathrm{U}$} & \multicolumn{8}{|c|}{ Isotopic ratio } & \multicolumn{6}{|c|}{ Apparent age (Ma) } \\
\hline & & & & $\mathrm{b}$ & $\pm 1 \sigma$ & $\mathrm{J}$ & $\pm 1 \sigma$ & $\mathrm{Pb} /{ }^{238} \mathrm{U}$ & $\pm 1 \sigma$ & $\mathrm{h}$ & $\pm 1 \sigma$ & & $\pm 1 \sigma$ & & $\pm 1 \sigma$ & 208 & \\
\hline 1 & 8 & 9 & 1 & 80 & 0.00086 & 41 & 0.00043 & 416 & 0.00003 & 65 & 00011 & 26 & 0.2 & 27 & 0.4 & 3 & 2.2 \\
\hline $0-02$ & 35.1 & 1236.9 & os & 0.04697 & 0.00433 & 0.01853 & 77 & 0.00286 & 0. & 0.0 & 0.06 & 4 & 4 & & 1.7 & & 6.8 \\
\hline TYC-88-03 & 39.2 & 2573.4 & 0.02 & 0.04695 & 0.00233 & 0.02113 & 0.00101 & 0.00327 & 0.00004 & 0.00313 & 0.00031 & 21.0 & 0.2 & 21.2 & 1.0 & 1 & 5.2 \\
\hline TYC-88-04 & 61.2 & 1922.1 & 0.03 & 0.04854 & 0.00166 & 0.02094 & 0.00068 & 0.00313 & 0.00003 & 0.00173 & 0.00013 & 20.1 & 0.2 & 21.0 & 0.7 & 35.0 & 2.6 \\
\hline TYC-88-05 & 19.5 & 1838.5 & 0.01 & 0.04654 & 0.00175 & 0.02106 & 0.00076 & 0.00328 & 0.00003 & 0.00099 & 0.00034 & 21.1 & 0.2 & 21.2 & 0.8 & 20.0 & 6.9 \\
\hline TYC-88-06 & 45.1 & 1785.7 & 0.03 & 0.04751 & 0.00186 & 0.02155 & 0.00081 & 0.00329 & 0.00003 & 0.00196 & 0.00019 & 21.2 & 0.2 & 21.6 & 0.8 & 39.5 & 3.8 \\
\hline TYC-88-07 & 116.3 & 2106.6 & 0.06 & 0.04496 & 0.00151 & 0.01774 & 0.00057 & 0.00286 & 0.00002 & 0.00102 & 0.00006 & 18.4 & 0.2 & 17.9 & 0.6 & 20.6 & 1.3 \\
\hline-08 & 59.1 & 17.5 & 0.04 & 0.04646 & 0.00179 & 0.01853 & 0 & 0.00289 & 0. & 57 & 0.00012 & 18.6 & 0.2 & 18 & 0.7 & 31.8 & 2.4 \\
\hline TYC-88-09 & 36.1 & 2238.7 & 0.02 & 0.04563 & 0.00143 & 0.02044 & 0.00061 & 0.00325 & 0.00003 & 0.00112 & 0.00020 & 20.9 & 0.2 & 20.5 & 0.6 & 22.6 & 4.1 \\
\hline TYC- $88-10$ & 25.8 & 1042.3 & 0.02 & 0.04614 & 0.00230 & 0.01864 & 0.00091 & 0.00293 & 0.00003 & 0.00148 & 0.00023 & 18.9 & 0.2 & 18.7 & 0.9 & 30.0 & 4.6 \\
\hline TYC-88-11 & 34.4 & 2628.0 & 0.01 & 0.04523 & 0.00113 & 0.02295 & 0.00053 & 0.00368 & 0.00003 & 0.00149 & 0.00018 & 23.7 & 0.2 & 23.0 & 0.5 & 30.1 & 3.6 \\
\hline TYC-88-12 & 26.2 & 2102.5 & 0.01 & 0.04477 & 0.00139 & 0.02037 & 0.00060 & 0.00330 & 0.00003 & 0.00172 & 0.00027 & 0 & 0.2 & 20 & 0.0 & 10 & 5.4 \\
\hline $8-1$ & 37.2 & 2666.1 & 0.01 & 85 & 0.00126 & 551 & 0 & 325 & 0. & 08 & 0. & 20 & 0.2 & 20 & 0 & 21.7 & .2 \\
\hline TYC-88-14 & 46.4 & 1971.5 & 0.02 & 0.04728 & 0.00227 & 0.01904 & 0.00088 & 0.00292 & 0.00003 & 0.00109 & 0.00014 & 18.8 & 0.2 & 19.1 & 0.9 & 22.1 & 2.8 \\
\hline TYC-88-15 & 74.9 & 1930.6 & 0.04 & 0.04424 & 0.00156 & 0.01724 & 0.00058 & 0.00283 & 0.00002 & 0.00104 & 0.00009 & 18.2 & 0.2 & 17.4 & 0.6 & 21.0 & 1.8 \\
\hline TYC-88-16 & 61.9 & 1816.3 & 0.03 & 0.04709 & 0.00170 & 0.01901 & 0.00065 & 0.00293 & 0.00003 & 0.00112 & 0.00011 & 18.9 & 0.2 & 19.1 & 0.7 & 22.6 & 2.2 \\
\hline$-88-17$ & 32. & 39.6 & 0. & 667 & 0.00141 & 96 & 0 & 326 & 0.00003 & 27 & 0. & 21.0 & 0.2 & 21 & 0.6 & 25.6 & 3.9 \\
\hline $3-18$ & 70.2 & 1686.3 & 0.0 & 01 & 245 & 752 & 0. & 282 & 0.0 & 10 & 0.0 & 18.2 & 0.2 & 17 & 0.9 & & 2.9 \\
\hline TYC-88-19 & 24.0 & 2704.1 & 0.01 & 0.04747 & 0.00127 & 0.02341 & 0.00059 & 0.00358 & 0.00003 & 0.00376 & 0.00032 & 23.0 & 0.2 & 23.5 & 0.6 & 75.9 & 6.4 \\
\hline TYC-88-20 & 31.8 & 2669.3 & 0.01 & 0.04609 & 0.00131 & 0.02087 & 0.00056 & 0.00329 & 0.00003 & 0.00137 & 0.00020 & 21.1 & 0.2 & 21.0 & 0.6 & 27.6 & 4.1 \\
\hline TYC-88-21 & 39.6 & 2165.7 & 0.02 & 0.04726 & 0.00154 & 0.02140 & 0.00066 & 0.00329 & 0.00003 & 0.00295 & 0.00020 & 21.1 & 0.2 & 21 & 0.7 & 59.5 & 4.0 \\
\hline $8-22$ & 81.2 & 2222.1 & 0.6 & 556 & 0.00161 & 0.01850 & 0.00062 & 0.00295 & 0.00003 & & 0.00010 & & 0.2 & & 0. & & 2.1 \\
\hline TYC-88-23 & 137.0 & 7195.0 & 0.02 & 0.04741 & 0.00084 & 0.02681 & 0.00042 & 0.00410 & 0.00003 & 0.00231 & 0.00008 & 26.4 & 0.2 & 26.9 & 0.4 & 46.6 & 1.6 \\
\hline TYC- $88-24$ & 51.0 & 1636.0 & 0.03 & 0.04709 & 0.00208 & 0.01925 & 0.00082 & 0.00297 & 0.00003 & 0.00093 & 0.00014 & 19.1 & 0.2 & 19.4 & 0.8 & 18.7 & 2.9 \\
\hline TYC-88-25 & 58.3 & 1737.5 & 0.03 & 0.04438 & 0.00197 & 0.01772 & 0.00076 & 0.00290 & 0.00003 & 0.00135 & 0.00012 & 18.6 & 0.2 & 17.8 & 0.8 & 27.3 & 2.4 \\
\hline$C-88-26$ & 75.1 & 2491.8 & 0.0 & 0.04633 & 0.00139 & 0.02083 & 0.00059 & 0.00326 & 0.00003 & 0.00128 & 0.00010 & 21.0 & 0.2 & 20.9 & 0.6 & 25.9 & 1.9 \\
\hline TYC-88-27 & 72.5 & 1835.9 & 0.04 & 0.04769 & 0.00179 & 0.01944 & 0.00070 & 0.00296 & 0.00003 & 0.00155 & 0.00011 & 19.0 & 0.2 & 19.5 & 0.7 & 31.3 & 2.3 \\
\hline TYC-88-28 & 115.9 & 2924.6 & 0.04 & & 0.00125 & & 0.00048 & & 02 & & & 2 & 0.2 & th & 0.5 & 3.3 & 1.3 \\
\hline $8-29$ & 17.3 & 1007.6 & 0.02 & 0.04620 & 0.00232 & 0.01805 & 0.00088 & 0.00283 & 0.00003 & 51 & 0.00036 & 18.2 & 0.2 & 18.2 & 0.9 & 30.5 & 7.3 \\
\hline TYC-88-30 & 23.0 & 914.6 & 0.03 & 0.04550 & 0.00272 & 0.01814 & 0.00106 & 0.00289 & 0.00003 & 0.00178 & 0.00026 & 18.6 & 0.2 & 18.3 & 1.1 & 36.0 & 5.3 \\
\hline TYC-88-31 & 38.4 & 2122.9 & 0.02 & 0.04691 & 0.00146 & 0.02101 & 0.00062 & 0.00325 & 0.00003 & 0.00159 & 0.00017 & 20.9 & 0.2 & 21.1 & 0.6 & 32.1 & 3.5 \\
\hline TYC-88-32 & 35.4 & 1566.4 & 0.02 & 0.04615 & 0.00163 & 0.01961 & 0.00066 & 0.00308 & 0.00003 & 0.00173 & 0.00016 & 19.8 & 0.2 & 19.7 & 0.7 & 35.0 & 3.3 \\
\hline
\end{tabular}

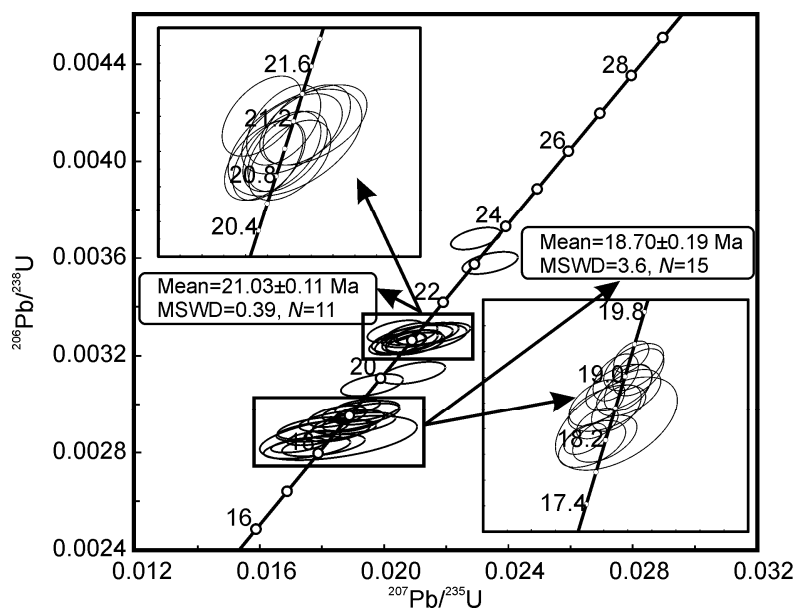

Figure 5 U-Pb concordia diagram for zircons from sample TYC-88 of the leucogranite. important transformation of tectonic regime from N-S extension to $\mathrm{N}-\mathrm{S}$ contraction occurred after $18.7 \mathrm{Ma}$ in our study area in northern Himalaya.

\subsection{Middle-Miocene transformation of tectonic regime in Himalayan orogen}

Based on the analysis of the structure and chronology of the leucogranite in Gyirong area, we propose that the transformation of tectonic regime from $\mathrm{N}-\mathrm{S}$ extension to $\mathrm{N}-\mathrm{S}$ contraction occurred after 18.7 Ma in the Gyirong area. In the Dinggye and Yadong areas of northern Himalaya, the N-S extensional STDS was cut and offset by the E-W extensional NSTRs $[17,18]$. All of NSTRs present the active ages of 19-7 Ma [4-10,12-17,22,28,30-48] (Figure 7), which are coeval with the south-direct thrust $(<18.7 \mathrm{Ma})$ of asymmetric 


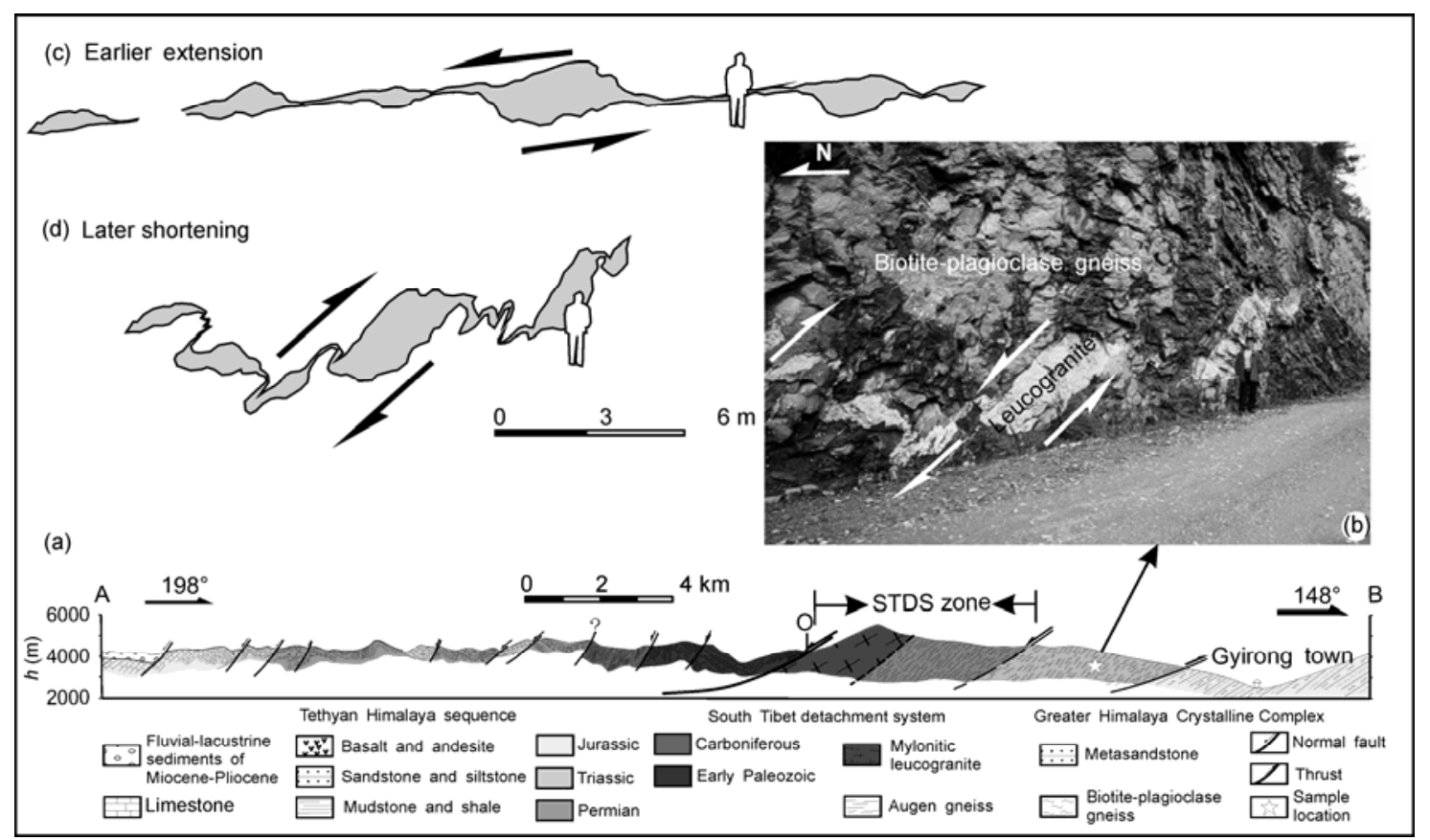

Figure 6 Structures of the Himalayan orogen in Gyirong area and the reconstruction of leucogranite. (a) Cross-section across the STDS in the Gyirong area (location is seen in Figure 2); (b) leucogranitic veins forming south-vergent asymmetric folds in GHC gneiss; (c) early phase of extension; (d) later thrusting and shorting of the leucogranite.

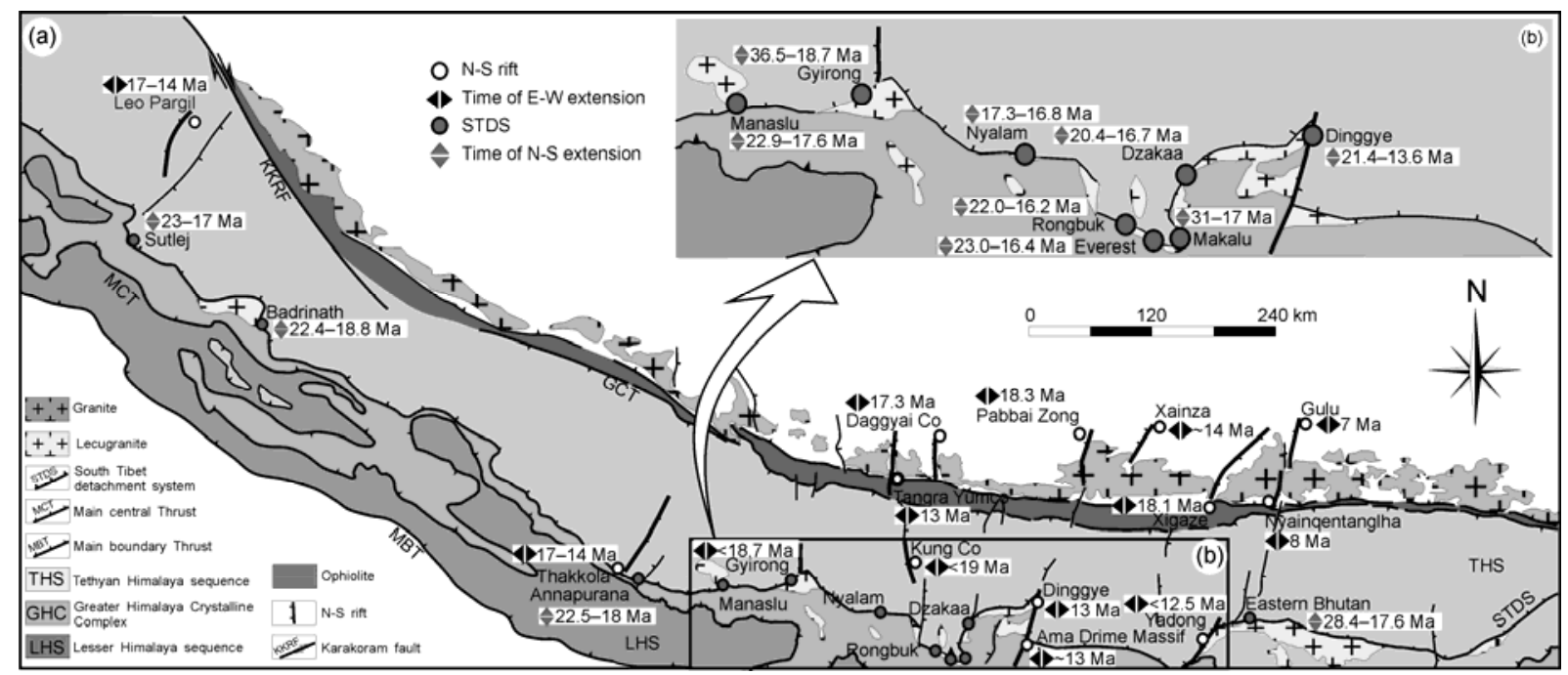

Figure 7 Summary diagram of the ages of STDS and NSTRs in the Himalayan orogen (data from [4-10,12-17,22,28,30-48]).

folds in this study. This confirms the view that NSTR is probably the result of N-S contraction [29] and provides unequivocal evidence for the transformation of tectonic regime.

In order to accurately constrain the time of the transformation of tectonic regime from N-S extension to N-S contraction, we summarize and analyze the ages of STDS and NSTRs in Gyirong and other areas in Himalayan orogen (Figure 7) [4-10,12-17,22,28,30-48]. The result shows that the STDS was active from ca. 36 to $13 \mathrm{Ma}$ with the major activity at ca. 28-13 Ma and the NSTRs were active from ca. 19 to $7 \mathrm{Ma}$ with a peak ages of 19-13 Ma. All the analyses prove that the Himalayan orogen was controlled by the regime of N-S extension from ca. 28 to 19 Ma. During ca. 19-13 Ma, it was controlled by both the N-S extension and $\mathrm{N}-\mathrm{S}$ contraction regime, implying a transition from $\mathrm{N}-\mathrm{S}$ extension to N-S contraction. Since $13 \mathrm{Ma}$, the regime of $\mathrm{N}-\mathrm{S}$ contraction was dominant. The U-Pb/U-(Th)-Pb ages of zircon/monazite from leucogranites and ${ }^{40} \mathrm{Ar} /{ }^{39} \mathrm{Ar}$ ages of mica from leucogranites and meta-sedimentary rocks in Himalayan orogen (Figure 8 and Table S1) [1,4-13,15-18, 22-24,30,34-83] show that the peak ages of leucogranites are roughly between $24 \mathrm{Ma}$ and $13 \mathrm{Ma}$, while the peak 
${ }^{40} \mathrm{Ar} /{ }^{39} \mathrm{Ar}$ ages are around $18-13 \mathrm{Ma}$. This means the emplacement of the leucogranites culminated at the same time as the ${ }^{40} \mathrm{Ar} /{ }^{39} \mathrm{Ar}$ cooling ages during ca. $18-13 \mathrm{Ma}$, which suggests a rapid cooling at this time. The rapid cooling event was probably related to the interaction of the extension of STDS, and uplift and erosion caused by the orogeny of N-S contraction, indicating a transition and adjustment from extension and collapse to contraction and uplift. Thus we suggest the transformation of tectonic regime from N-S extension to N-S contraction occurred in middle-Miocene, i.e. the Himalayan orogen experienced a transition and adjustment from N-S extension to N-S contraction during ca. 19-13 Ma, and it was controlled by the regime of $\mathrm{N}-\mathrm{S}$ contraction since $13 \mathrm{Ma}$, indicating the transformation of tectonic regime at $\sim 13 \mathrm{Ma}$.

\subsection{Geodynamic implications on the transformation of tectonic regime in the Himalayan orogen}

Three categories of tectonic scenario have been proposed to interpret the transformation of tectonic regime: (1) Lateral extrusion model: the northward push of India led to the eastward extrusion of Tibet plateau in the form of eastward movement of the upper crust or "channel flow" of the middle-lower crust $[84,85]$. The eastward extrusion resulted in the regime of E-W extension. (2) Southward flow with a divergent radial component: the southward spreading of mid-crust in Tibet produced an E-W radial component of flow, causing the onset of the observed E-W extension and the formation of NSTR [48]. (3) Zhang et al. [1] proposed a new tectonic scenario that the transformation of tectonic regime was related to the rate of India-Asia convergence. When the convergence was slow, could the force could not sustain the thickened orogen, with the Himalayan orogen experiencing a relaxation and the northern Himalaya witnessing a mountain collapse process, i.e., the extension of the STDS. At this time, the regime of N-S extension was dominant. When the India-Asia convergence speeded up, the Himalaya experienced a rapid deformation, resulting in

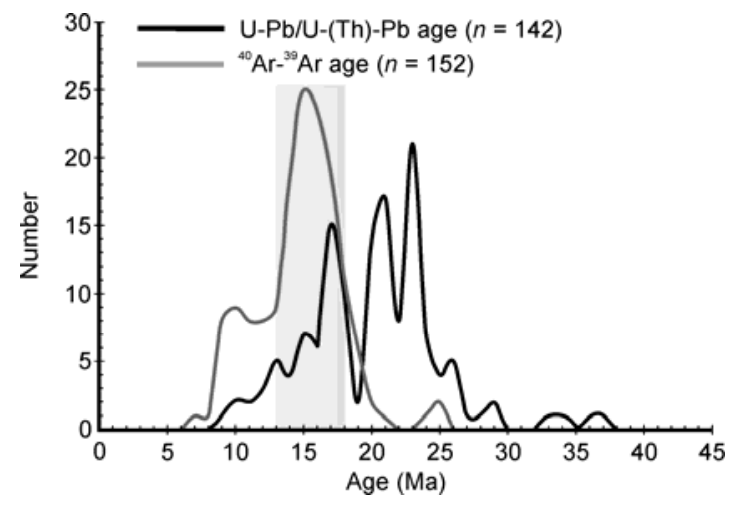

Figure 8 Statistical diagram of the U-Pb/U-(Th)- $\mathrm{Pb}$ ages of leucogranites and ${ }^{40} \mathrm{Ar} /{ }^{39} \mathrm{Ar}$ ages of leucogranites and metasedimentary rocks in Himalayan orogen (data from [1,4-13,15-18,22-24,30,34-83]). the thrusting and shorting. The NSTR and south-vergent asymmetric folds formed and tectonic regime was N-S contraction.

Based on paleomagnetic data, White and Lister (2012) [86] estimated the rate of India-Asia convergence since collision. Before $20 \mathrm{Ma}$, the rate of India-Asia convergence was slow. During 19-13 Ma, it was an alternant process of speeding up and slowing down. Since $13 \mathrm{Ma}$, the convergence rate speeded up again. The tomography of Himalayan orogen reveals multiple episodes of continental subduction [87]. At $15 \mathrm{Ma}$, the breaking off of the steep subducted slab caused gentle subduction and increase in the rate of horizontal convergence [88]. The northerly moving Indian plate rotated clockwise in Miocene, which also probably altered the convergence rate and resulted in the transformation of tectonic regime $[89,90]$. All these features support the model proposed by Zhang et al. [1]. Integrating the structural reconstruction with above model, we suggest an evolutionary process and the transformation of tectonic regime in the northern Himalaya as follows. (1) From ca. 28 to $19 \mathrm{Ma}$, the India-Asia convergence rate was slow, when the Himalayan orogen experienced a collapse and the STDS was intensely active under a tectonic regime of N-S extension. (2) From ca.19 to $13 \mathrm{Ma}$, the rate of India-Asia convergence changed, when the STDS and NSTR were active alternately. The tectonic regime was in a period of transition and adjustment from N-S extension to N-S contraction. (3) After ca. $13 \mathrm{Ma}$, the rapid India-Asia convergence caused intense contraction, leading to the formation of the asymmetric folds in Gyirong area and the activation of the NSTR.

\section{Conclusion}

(1) The leucogranite veins in the footwall of the STDS of Gyirong area, south Tibet, were emplaced at 21.03-18.7 Ma. The region experienced an earlier top-down-to-north extension and a later south-direct thrusting, indicating a tectonic transformation after $18.7 \mathrm{Ma}$.

(2) The Himalayan orogen experienced a transformation of tectonic regime from $\mathrm{N}-\mathrm{S}$ extension to $\mathrm{N}-\mathrm{S}$ contraction in middle-Miocene. The accomplishment of the tectonic transformation was at ca.13 Ma.

(3) The transformation of tectonic regime in Himalayan orogen is controlled by alteration in the rate of India-Asia convergence.

Thanks to Prof. Ye Kai for his help and support in CL images in Institute of Geology and Geophysics, CAS, Beijing. We express our appreciation to Yang Di and Yue Yahui for their help in LA-ICP-MS U-Pb zircon dating at the LA-ICPMS Laboratory of the Key Laboratory of Continental Collision and Plateau Uplift, Institute of Tibetan Plateau Research, Chinese Academy Sciences, Beijing. We are particularly grateful to Prof. Santosh for his improvement in this manuscript. Finally we thank the anonymous reviewers for their constructive suggestions and comments. This work was supported by the National Natural Science Foundation of China (41172176 and 41121062) and China Geological Survey (1212011121066). 
1 Zhang J J, Santosh M, Wang X X, et al. Tectonics of the northern Himalaya since the India-Asia collision. Gondwana Res, 2012, 21: 939-960

2 Xu Z Q, Yang J S, Li H B, et al. Orogenic Plateau-Terrane Amalgamation, Collision and Uplift in the Qinghai-Tibet Plateau (in Chinese). Beijing: Geological Publishing House, 2007. 1-458

3 Yin A. Cenozoic tectonic evolution of the Himalayan orogeny as constrained by along-strike variation of structural geometry, exhumation history, and foreland sedimentation. Earth-Sci Rev, 2006, 76: $1-131$

4 Coleman M, Hodges K. Evidence for Tibetan Plateau uplift before 14-Myr ago from a new minimum age for East-West extension. Nature, 1995, 374: 49-52

5 Harrison T M, Mckeegan K D, LeFort P. Detection of inherited monazite in the Manaslu leukogranite by ${ }^{208} \mathrm{~Pb} /{ }^{232} \mathrm{Th}$ ion microprobe dating-crystallization age and tectonic implications. Earth Planet Sci Lett, 1995, 133: 271-282

6 Harrison T M, Grove M, McKeegan K D, et al. Origin and episodic emplacement of the Manaslu intrusive complex, central Himalaya. J Petrol, 1999, 40: 3-19

7 Searle M P, Parrish R R, Hodges K V, et al. Shisha Pangma leucogranite, south Tibetan Himalaya: Field relations, geochemistry, age, origin, and emplacement. J Geol, 1997, 105: 295-317

8 Searle M P, Simpson R L, Law R D, et al. The structural geometry, metamorphic and magmatic evolution of the Everest massif, High Himalaya of Nepal-South Tibet. J Geol Soc Lond, 2003, 160: 345366

9 Hodges K V. The Thermodynamics of Himalayan Orogenesis. In: Treloar P J, O'Brien P J, eds. What Drives Metamorphism and Metamorphic Reactions? Geol Soc Lond Spec Publ, 1998, 138: 7-22

10 Dèzes P J, Vannay J C, Steck A, et al. Synorogenic extension: Quantitative constraints on the age and displacement of the Zanskar shear zone (northwest Himalaya). Geol Soc Am Bull, 1999, 111: 364-374

11 Murphy M A, Harrison T M. Relationship between leucogranites and the Qomolangma detachment in the Rongbuk Valley, south Tibet. Geology, 1999, 27: 831-834

12 Godin L, Grujic D, Law R D, et al. Channel flow, ductile extrusion and exhumation in continental collision zones: An introduction. In: Law R D, Searle M P, Godin L, eds. Geol Soc Lond Spec Publ, 2006, 268: 1-23

13 Cottle J M, Jessup M J, Newell D L, et al. Structural insights into the early stages of exhumation along an orogen-scale detachment: The South Tibetan Detachment system, Dzakaa Chu section, eastern Himalaya. J Struct Geol, 2007, 29: 1781-1797

14 Kellett D A, Grujic D, Warren C, et al. Metamorphic history of a synconvergent orogen-parallel detachment: The South Tibetan detachment system, Bhutan Himalaya. J Metamorph Geol, 2010, 28: 785808

15 Leloup P H, Maheo G, Arnaud N, et al. The South Tibet detachment shear zone in the Dinggye area: Time constraints on extrusion models of the Himalayas. Earth Planet Sci Lett, 2010, 292: 1-16

16 Sachan H K, Kohn M J, Saxena A, et al. The Malari leucogranite, Garhwal Himalaya, northern India: Chemistry, age, and tectonic implications. Geol Soc Am Bull, 2010, 122: 1865-1876

17 Edwards M A, Harrison T M. When did the roof collapse? Late Miocene north-south extension in the high Himalaya revealed by $\mathrm{Th}-\mathrm{Pb}$ monazite dating of the Khula Kangri granite. Geology, 1997, 25: 543-546

18 Zhang J J, Guo L. Structure and geochronology of the southern Xainza-Dinggye rift and its relationship to the south Tibetan detachment system. J Asian Earth Sci, 2007, 29: 722-736

19 Grujic D, Coutand I, Bookhagen B, et al. Climatic forcing of erosion, landscape, and tectonics in the Bhutan Himalayas. Geology, 2006, 34: 801-804

20 Robinson D M, DeCelles P G, Copeland P. Tectonic evolution of the Himalayan thrust belt in western Nepal: Implications for channel flow models. Geol Soc Am Bull, 2006, 118: 865-885

21 Webb A A G, Yin A, Harrison T M, et al. The leading edge of the Greater Himalayan Crystalline complex revealed in the NW Indian
Himalaya: Implications for the evolution of the Himalayan orogen. Geology, 2007, 35: 955-958

22 Yang X Y, Zhang J J, Qi G W, et al. Structure and deformation around the Gyirong basin, north Himalaya, and onset of the south Tibetan detachment. Sci China Ser D-Earth Sci, 2009, 52: 1046-1058

23 Aoya M, Wallis S R, Kawakami T, et al. The Malashan Gneiss Dome in south Tibet: Comparative study with the Kangmar Dome with Special reference to kinematics of deformation and origin of associated granites. In: Law R D, Searle M P, Godin L, eds. Geol Soc Lond Spec Publ, 2006, 268: 471-495

24 Kawakami T, Aoya M, Wallis S R, et al. Contact metamorphism in the Malashan dome, North Himalayan gneiss domes, southern Tibet: An example of shallow extensional tectonics in the Tethys Himalaya. J Metamorph Geol, 2007, 25: 831-853

25 Van Achterbergh E, Ryan C, Jackson S, et al. Appendix 3 Data Reduction Software for La-ICP-MS in "Laser-Ablation-ICPMS in the Earth Sciences". Mineral Assoc Can Short Course, 2001, 29: 239243

26 Ludwig K R. ISOPLOT 3.0: A Geochronological Toolkit for Microsoft Excel. Special publication No.4. Berkeley: Berkeley Geochronology Center. 2003

27 Corfu F, Hanchar J M, Hoskin P W O, et al. Altas of Zircon Textures. In: Hanchar J M, Hoskin P W O, eds. Zircon. Reviews in Mineralogy and Geochemisty. Mineral Soc Am, 2003, 53: 469-500

28 Coleman M E. U-Pb constraints on Oligocene-Miocene deformation and anatexis within the Central Himalaya, Marsyandi valley, Nepal. Am J Sci, 1998, 298: 553-571

29 Zhang J J. A review on the extensional structures in the northern Himalaya and southern Tibet (in Chinese). Geol Bull Chin, 2007, 26: 639-649

30 Deniel C, Vidal P, Fernandez A, et al. Isotopic study of the Manaslu granite (Himalaya, Nepal): Inferences on the age and source of Himalayan leukogranites. Contrib Mineral Petrol, 1987, 96: 78-92

31 Groppo C, Rubatto D, Rolfo F, et al. Early Oligocene partial melting in the main Central Thrust Zone (Arun valley, eastern Nepal Himalaya). Lithos, 2010, 118: 287-301

32 Scaillet B, Searle M P. Mechanisms and timescales of felsic magma segregation, ascent and emplacement in the Himalaya. In: Law R D, Searle M P, Godin L, eds. Geol Soc Lond Spec Publ, 2006, 268: 293308

33 Yu J J, Zeng L S, Gao L E, et al. Early Miocene leucogranite in Dinggye area, southern Tibet: Formation mechanism and tectonic implication (in Chinese). Acta Petrol Sin, 2011, 27: 1961-1972

34 Copeland P, Harrison T M, Lefort P. Age and cooling history of the Manaslu granite: Implications for Himalayan Tectonics. J Volcanol Geoth Res, 1990, 44: 33-50

35 Harrison T M, Lovera O M, Grove M. New insights into the origin of two contrasting Himalayan granite belts. Geology, 1997, 25: 899-902

36 Hodges K V, Parrish R R, Searle M P. Tectonic evolution of the central Annapurna Range, Nepalese Himalayas. Tectonics, 1996, 15: 1264-1291

37 Cottle J M, Jessup M J, Newell D L, et al. Geochronology of granulitized eclogite from the Ama Drime Massif: Implications for the tectonic evolution of the South Tibetan Himalaya. Tectonics, 2009, 28: $1-25$

38 Kali E, Leloup P H, Arnaud N, et al. Exhumation history of the deepest central Himalayan rocks (Ama Drime range): Key pressure-temperature deformation-time constraints on orogenic models. Tectonics, 2010, 29: TC2014

39 Thiede R C, Arrowsmith J R, Bookhagen B, et al. Dome formation and extension in the Tethyan Himalaya, Leo Pargil, northwest India. Geol Soc Am Bull, 2006, 118: 635-650

40 Harrison T M, Copeland P, Kidd W S F, et al. Activation of the Nyainquentanghla Shear Zone: Implications for uplift of the southern Tibetan Plateau. Tectonics, 1995, 14: 658-676

41 Williams H, Turner S, Kelley S, et al. Age and composition of dikes in southern Tibet: New constraints on the timing of east-west extension and its relationship to post-collisional volcanism. Geology, 2001, 29: $339-342$ 
42 Stockli D F, Taylor M, Yin A, et al. Late Miocene-Pliocene inception of E-W extension in Tibet as evidenced by apatite (U-Th)/He data. Geol Soc Am Bull, 2002, 34: 411

43 Garzione C N, DeCelles P G, Hodkinson D G, et al. East-west extension and Miocene environmental change in the southern Tibetan Plateau; Thakkhola Graben, central Nepal. Geol Soc Am Bull, 2003, 115: 3-20

44 Murphy M A, Copeland P. Transtensional deformation in the central Himalaya and its role in accommodating growth of the Himalayan orogeny. Tectonics, 2005, 24: 1-19

45 Saylor J E, DeCelles P G, Quade J. Climate-driven environmental change in the Zhada basin, southwestern Tibet. Geosphere, 2010, 6: 74-92

46 Hintersberger E, Thiede R C, Strecker M R, et al. East-west extension in the NW Indian Himalaya. Geol Soc Am Bull, 2010, 122: 1499-1515

47 Lee J, Hager C, Simon R, et al. Middle to late Miocene extremely rapid exhumation and thermal re-equilibration in the Kung Co rift, southern Tibet. Tectonics, 2011, 30: 1-26

48 Mayumi M, Simon R W, Mutsuki A, et al. E-W extension at $19 \mathrm{Ma}$ in the Kung Co area, S. Tibet: Evidence for contemporaneous E-W and N-S extension in the Himalayan orogeny. Earth Planet Sci Lett, 2012, 325-326: 10-20

49 Annen C, Scaillet B, Sparks R S J. Thermal constraints on the emplacement rate of a large intrusive complex: The Manaslu leucogranite, Nepal Himalaya. J Petrol, 2006, 47: 71-95

50 Aoya M, Wallis S R, Terada K, et al. North-south extension in the Tibetan crust triggered by granite emplacement. Geology, 2005, 33: 853-856

51 Carosi R, Montomoli C, Rubatto D, et al. Normal-sense Shear Zones in the Core of the Higher Himalayan Crystallines (Bhutan Himalaya): Evidence for Extrusion? In: Law R D, Searle M P, Godin L, eds. Geol Soc Lon Spec Publ, 2006, 268: 425-444

52 Catlos E J, Harrison T M, Manning C E, et al. Records of the evolution of the Himalayan orogen from in situ $\mathrm{Th}-\mathrm{Pb}$ ion microprobe dating of monazite: Eastern Nepal and western Garhwal. J Asian Earth Sci, 2002, 20: 459-479

53 Chambers J, Caddick M, Argles T. et al. Empirical constraints on extrusion mechanisms from the upper margin of an exhumed highgrade orogenic core, Sutlej valley, NW India. Tectonophysics, 2009, 477: 77-92

54 Daniel C G, Hollister L S, Parrish R R, et al. Exhumation of the Main Central Thrust from lower crustal depths, Eastern Bhutan Himalaya. J Metamorph Geol, 2003, 21: 317-334

55 Ding L, Zhong D L, Yin A, et al. Cenozoic structural and metamorphic evolution of the eastern Himalayan syntaxis (Namche Barwa). Earth Planet Sci Lett, 2001, 192: 423-438

56 Grassman B, Vannay J, Rahn M, et al. Active tectonic exhumation of high-grade metamorphic rocks in the frontal part of the Himalayan orogen: ${ }^{40} \mathrm{Ar} /{ }^{39} \mathrm{Ar}$ and fission track geochronological evidence from the Sutlej valley (NW India). J Geophys Res, 2001, 114: 24-25

57 Hubbard M S, Harrison T M. ${ }^{40} \mathrm{Ar} /{ }^{39} \mathrm{Ar}$ age constraints on deformation and metamorphism in the Main Central Thrust zone and Tibetan slab, eastern Nepal Himalaya. Tectonics, 1989, 8: 865-880

58 Hubbard M S. Thermobarometric constraints on the thermal history of the Main Central Thrust zone and Tibetan slab, eastern Nepal Himalaya. J Metamorph Geol, 1989, 7: 19-30

59 Kapp P, Taylor M, Stockli D, et al. Development of active low-angle normal fault systems during orogenic collapse: Insight from Tibet. Geology, 2008, 36: 7-10

60 Lee J, Hacker B R, Dinklage W S, et al. Evolution of the Kangmar Dome, southern Tibet: Structural, petrologic, and thermochronologic constraints. Tectonics, 2000, 19: 872-895

61 Lee J, McClelland W, Wang Y, et al. Oligocene-Miocene middle crustal flow in southern Tibet: Geochronology of Mabja Dome. Geol Soc Lond Spec Public, 2006, 268: 445-469

62 Lee J, Whitehouse M J. Onset of mid-crustal extensional flow in southern Tibet: Evidence from U/Pb zircon ages. Geology, 2007, 35: $45-48$
63 Liu Y, Siebel W, Massonne H J, et al. Geochronological and petrological constraints for tectonic evolution of the central Greater Himalayan Sequence in the Kharta area, southern Tibet. J Geol, 2007, 115: 215-230

64 Murphy M A, Yin A, Kapp P, et al. Structural evolution of the Gurla Mandhata detachment system, southwest Tibet: Implications for the eastward extent of the Karakoram fault system. Geol Soc Am Bull, 2002, 114: 428-447

65 Noble S R, Searle M P. Age of crustal melting and leukogranite formation from $\mathrm{U}-\mathrm{Pb}$ zircon and monazite dating in the western Himalaya, Zanskar, India. Geology, 1995, 23: 1135-1138

66 Quigley M, Yu L J, Liu X H, et al. ${ }^{40} \mathrm{Ar} /{ }^{39} \mathrm{Ar}$ thermochronology of the Kampa Dome, southern Tibet: Implications for tectonic evolution of the North Himalayan gneiss domes. Tectonophysics, 2006, 421: 269-297

67 Schärer U, Xu R H, Allègre C J. U-(Th)-Pb systematics and ages of Himalayan leukogranites, south Tibet. Earth Planet Sci Lett, 1986, 77: 35-48

68 Schärer U. The effect of initial ${ }^{230}$ Th disequilibrium on young U-Pb ages: The Makalu case, Himalaya. Earth Planet Sci Lett, 1984, 67: 191-204

69 Schneider D A, Edwards M A, Kidd W S F, et al. Early Miocene anatexis identified in the western syntaxis, Pakistan Himalaya. Earth Planet Sci Lett, 1999, 167: 121-129

70 Schneider D A, Edwards M A, Kidd W S F, et al. Tectonics of Nanga Parbat, western Himalaya: Synkinematic plutonism within the doubly vergent shear zones of a crustal-scale pop-up structure. Geology, 1999, 27: 999-1002

71 Searle M P, Noble S R, Hurford A J, et al. Age of crustal melting, emplacement and exhumation history of the Shivling leucogranite, Garhwal Himalaya. Geol Mag, 1999, 136: 513-525

72 Simpson R L, Parrish R R, Searle M P, et al. Two episodes of monazite crystallization during metamorphism and crustal melting in the Everest region of the Nepalese Himalaya. Geology, 2000, 28: 403406

73 Sorkhabi R B, Stump E, Foland K A, et al. Fission-track and ${ }^{40} \mathrm{Ar} /{ }^{39} \mathrm{Ar}$ evidence for episodic denudation of the Gangotri granites in the Garhwal Higher Himalaya, India. Tectonophysics, 1996, 260: 187-199

74 Stuwe K, Foster D. ${ }^{40} \mathrm{Ar} /{ }^{39} \mathrm{Ar}$, pressure, temperature and fission track constraints on the age and nature of metamorphism around the main central thrust in the eastern Bhutan Himalaya. J Asian Earth Sci, 2001, 19: 85-95

75 Vannay J C, Hodges K V. Tectonometamorphic evolution of the Himalayan metamorphic core between the Annapurna and Dhaulagiri, central Nepal. J Metamorph Geol, 1996, 14: 635-656

76 Viskupic K, Hodges K V. Monazite-xenotime thermochronometry: Methodology and an example from the Nepalese Himalaya. Contrib Mineral Petrol, 2001, 141: 233-247

77 Walker C B. The tectonothermal evolution of the high Himalayas in the Suru valley, NW Zanskar, with constraints from metamorphic modeling. Dissertation for the Doctoral Degree. Oxford: Faculty of Physical Sciences, University of Oxford, 1999. 1-330

78 Wobus C, Heimsath A, Whipple $\mathrm{K}$, et al. Active out-of-sequence thrust faulting in the central Nepalese Himalaya. Nature, 2005, 434: 1008-1011

79 Wu C D, Nelson K D, Wortman G, et al. Yadong cross structure and South Tibetan Detachment in the east central Himalaya $\left(89^{\circ}-90^{\circ} \mathrm{E}\right)$. Tectonics, 1998, 17: 28-45

$80 \mathrm{Xu}$ R. Metamorphism and Igneous Rocks in Xizang (Tibet). Beijing: Geological Publishing House, 1990. 287-321

81 Zeng L S, Liu J, Gao L, et al. Early Oligocene anatexis in the Yardoi gneiss dome, southern Tibet and geological implications. Chin Sci Bull, 2009, 54: 104-112

82 Zhang H F, Harris N, Parrish R, et al. U-Pb ages of Kude and Sajia leucogranites in Saffia dome from North Himalaya and their geological implications. Chin Sci Bull, 2004, 49: 2087-2092

83 Gong J F, Ji J Q, Sang H Q, et al. ${ }^{40} \mathrm{Ar} /{ }^{39} \mathrm{Ar}$ geochronology of highpressure granulite xenolith and its surrounding granite in central 
Himalaya (in Chinese). Acta Petrol Sin, 2006, 22: 2677-2686

84 Armijo R, Tapponnier P, Mercier J P T, et al. Quaternary extension in southern Tibet: Field observations and tectonic implications. J Geophys Res, 1986, 91: 13803-13872

85 Armijo R, Tapponnier P, Han T. Late Cenozoic right-lateral strikeslip faulting across southern Tibet. J Geophys Res, 1989, 94: $2787-$ 2838

86 White L H, Lister G S. The collision of India with Asia. J Geodyn, 2012, 56-57: 7-17

87 Replumaz A, Negredo A M, Guillot S, et al. Multiple episodes of continental subduction during Indian/Asia convergence: Insight from seismic tomography and tectonic reconstruction. Tectonophysics, 2010, 483: 125-134

88 Royden L H. The tectonic expression slab pull at continental convergent boundaries. Tectonics, 1993, 12: 303-325

89 Lee T Y, Lawver L A. Cenozoic plate reconstruction of the South China Sea region. Tectonophysics, 1994, 235: 149-180

90 Liu J L, Song Z J, Gao S Y, et al. The dynamic setting and processes of tectonic and magmatic evolution of the oblique collision zone between Indian and Eurasia plates: Exemplified by the tectonic evolution of the Three River region, eastern Tibet (in Chinese). Acta Petrol Sin, 22: 775-786

Open Access This article is distributed under the terms of the Creative Commons Attribution License which permits any use, distribution, and reproduction in any medium, provided the original author(s) and source are credited.

\section{Supporting Information}

Table S1 LA-ICP-MS U-Pb isotope data of zircon grains from the Penggongmiao granite and coexisting aplitic vein

The supporting information is available online at csb.scichina.com and www.springerlink.com. The supporting materials are published as submitted, without typesetting or editing. The responsibility for scientific accuracy and content remains entirely with the authors. 